\title{
Рецензия на книгу Sablin I. The Rise and Fall of Russia's Far Eastern Republic, 1905-1922. Nationalisms, Imperialisms, and Regionalisms in and after the Russian Empire ${ }^{1}$
}

Столетие российской революции и Гражданской войны вызвало ощутимый подъем региональных исследований. В последние годы вышло множество монографий и статей, прошли международные конференции и круглые столы, посвященные истории различных российских регионов в эту драматичную эпоху. Значительное внимание было обращено и на Дальний Восток в период 1917-1922 гг. По революции 1917 г. [6] и Гражданской войне на Дальнем Востоке [7] прошли крупные международные конференции. Рассмотрены также некоторые аспекты истории Дальнего Востока и, в частности, Дальневосточной республики (ДВР): повседневная жизнь [11], экономика [4], таможенное дело [3], внешняя политика [14], органы государственной безопасности $[13 ; 16]$, судебные учреждения [10]. В этом ряду, однако, не хватает общих исследований политической истории ДВР. Необходимость такой работы, с учетом накопленного опыта, назрела уже давно: последние крупные обобщающие работы по истории ДВР вышли 20-30 лет назад $[1 ; 8]$.

На этом фоне выход в свет монографии Ивана Саблина по истории Дальневосточной республики [17] уже сам по себе является заметным событием. Тем более для зарубежной историографии, в которой ДВР крайне редко становилась и становится объектом исследования. Создание ДВР еще с советских времен рассматривалось как согласованный и дальновидный план большевистского руководства и лично В.И. Ленина по мягкому, постепенному "поглощению" Дальнего Востока. Опираясь на новые архивные источники, И. Саблин подвергает критике эту концепцию и рассматривает ДВР как "продукт политического кризиса и компромисса, а не большевистского плана" $[17$, c. 15]. В этом смысле ДВР заслуживает внимания историков не только как "буферное" государство, но и как оригинальный, самобытный политический проект. Появившийся еще в 1990-е гг. взгляд на ДВР как на возможную демократическую альтернативу большевистскому проекту [15] в монографрии И. Саблина раскрывается с новых сторон. Во введении автор отмечает, что "формирование ДВР и более широкие революционные события на Дальнем Востоке России представили альтернативный сценарий в истории распада Российской империи и становления Советского Союза" [17, с. 16].

Однако наиболее привлекательным в работе И. Саблина является изучение истории ДВР в более широком контексте развития русского империализма и национализма в революционную эпоху. Отметим, что исследование изначально выходит за традиционные географические и хронологические рамки. И. Саблин большое внимание уделяет предреволющионному периоду истории Дальнего Востока. Такое внимание вполне оправдано, так как вписывается в современные историографические тренды: расширение рамок российской революции и "имперский поворот". Первый из этих трендов наметился давно, но наиболее ярко проявился после 2017 г. [19; 20]. Переосмысливаются и рамки Гражданской войны. Джонатан Смил, к примеру, считает,

1 Sablin I. The Rise and Fall of Russia's Far Eastern Republic, 1905-1922. Nationalisms, Imperialisms, and Regionalisms in and after the Russian Empire. London, New York: Routledge, 2019. $312 \mathrm{p}$

(C) Богололов И. К., 2020

БОГОМОЛОВ Игорь Константинович, канд. ист. наук, научный сотрудник Института научной информации по общественным наукам PAH (2. Москва). E-mail: boga_igor@mail.ru 
что в России была не одна, а несколько гражданских войн, слабо связанных между собой и длившихся вплоть до 1926 г. События на Дальнем Востоке Смил считал уже частью завершающего этапа, когда судьба Белого движения была предрешена [18, с. 220-226].

И. Саблин придерживается более традиционных рамок революции, говоря, например, о первой русской и Февральской револющии, а также об одной российской Гражданской войне. При этом автор поддерживает мнение, что присоединение ДВР стало фрактическим и символическим окончанием Гражданской войны. Эта трактовка вписывается в другой тренд - "имперский поворот", обозначивший смещение "фокуса внимания с центра к периферии - окраинам обширной империи" [5, с. 7]. С этой точки зрения ДВР выступает как своеобразный феномен в длительной трансформации Российской империи, поменявшей за эти годы обличие, название, идеологию, но оставшейся империей [2]. На обширном источниковом материале автор демонстрирует, как "имперская парадигма" и национализм сыграли роль в судьбе ДВР и общем итоге Гражданской войны на Дальнем Востоке.

Монография состоит из пяти глав. В первой главе рассматривается первый этап "имперской трансформации" между революцией 1905 г. и падением монархии. В этот период в политической жизни империи доминировал "леволиберальный национализм" [17, с. 33], предполагавший дальнейшее развитие империи путем укрепления местного самоуправления, поощрения местной инициативы, делегирования полномочий от центральных органов власти к местным. Дальний Восток служил ярким примером этого своеобразного симбиоза национализма, империализма и либерализма. Первая русская революция хоть прошла на Дальнем Востоке относительно спокойно, но значительно оживила политические дискуссии, усилила ожидание перемен. Хотя Государственная дума не стала "источником реформ", для дальневосточников она стала необходимой площадкой для дискуссий и обмена опытом. Тяготы, вызванные Первой мировой войной, подстегнули критику в адрес правительства. В это время сформировался "широкий леволиберальный национальный консенсус" [17, с. 38], ставший важнейшей почвой для революции 1917 г.

Во второй главе И. Саблин анализирует второй этап "имперской трансформации", продлившийся от Февральской революции до "укрепления большевистского контроля" над большей частью бывшей Российской империи $[17$, c. 83]. Как и в других регионах России, на Дальнем Востоке падение самодержавия было встречено с радостью и надеждами на лучшее будущее. Среди последних преобладали "умеренные" меньшевики и эсеры, да и местные большевики были гораздо больше петроградских настроены на диалог с политическими противниками. Этим объясняется и относительно спокойная обстановка на Дальнем Востоке весь 1917 г. Разгон Учредительного собрания "придал регионализму новый политический смысл" [17, с. 84]. Местные власти в Сибири и на Дальнем Востоке получили вполне законную возможность не подчиниться "новому самодержавию" в лице большевиков. Отличием Дальнего Востока была иностранная интервенция, значительно повлиявшая на местные настроения.

Третья глава посвящена борьбе за Дальний Восток в решающей фазе Гражданской войны. Несмотря на враждебное отношение населения к японским интервентам, большевики не решились вступить с Японией в открытый конфрликт. Новое государство на Дальнем Востоке должно было послужить "дымовой завесой для захвата региона и прекращения интервенции" [17, c. 134]. Не все в большевистском руководстве встретили этот план с пониманием, однако он все же был принят. 6 апреля 1920 г. ДВР была официально провозглашена, а в мае того же года - признана советским правительством. Хотя борьба с интервентами и остатками Белого движения продолжалась вплоть до осени 1922 г., создание ДВР стало важнейшим шагом Москвы на пути к присоединению Дальнего Востока. Значительную роль сыграла и японская интервенция. Пытаясь с помощью ввода войск остановить распространение большевистского влияния, японцы добились обратного результата: в глазах местного населения большевики представлялись "меньшим злом" по сравнению с иностранными захватчиками. 
В четвертой главе И. Саблин анализирует государственное устройство, внешнюю и внутреннюю политику ДВР. Создание объединенного ДВР осенью 1920 г. и последующее принятие ее Конституции Учредительным собранием

Дальнего Востока "можно рассматривать как триумфр большевистского плана, заставившего международное сообщество поверить в то, что регион добился своего независимого демократического и капиталистического государства" [17, с. 182]. Формально независимая, ДВР полностью контролировалась Москвой. Это сказывалось и на внутренней политике: формально объявленные права и свободы населения на практике нарушались. К осени 1921 г. ДВР считалась "советской провинцией, проводником советского империализма и форпостом радикализма и анархии" [17, с. 185].

Наконец, в пятой главе автор выделяет основные последствия создания ДВР, ее влияние и наследие в последующей истории СССР. Одним из главных факторов поражения антибольшевистских сил на Дальнем Востоке стало их сотрудничество с интервентами. ДВР эффективно эксплуатировала националистические по фрорме и содержанию лозунги борьбы с интервентами, что обеспечило более широкую социальную поддержку. В ДВР продолжалась юридическая и финансовая поддержка, распространение литературы и культуры национальных меньшинств. Однако эти преимущества постепенно были утрачены после вхождения ДВР в состав РСФСР 15 ноября 1922 г. Изменились и внешние обстоятельства. Экспорт революции перестал быть приоритетом для Москвы во второй половине 1920-х годов, что вызвало охлаждение к национальным движениям. В 1930 -е гг. это обернулось преследованием и репрессиями против национальных элит и основателей Дальневосточной республики.

Рецензируемая монография - одна из немногих до сих пор попыток охарактеризовать феномен Дальневосточной республики с точки зрения новых тенденций в историографии. При этом можно отметить и прикладное значение книги. Хотя основное внимание обращено на политические события, она дает представление о социально-экономическом развитии, общественных настроениях в ДВР и на всем Дальнем Востоке за длительный исторический период. Исследование И. Саблина, безусловно, большой шаг вперед для историографии Гражданской войны в России.

\section{Литература}

1. Азаренков А.А. "Демократический компромисс": идея "буфера" на Дальнем Востоке в планах и тактике политических сил - участников гражданской войны в России (январь 1920-январь 1921 гг.). Комсомольск-на-Амуре: Изд-во Комсом.-на-Амуре гос. пед. ун-та, 2001. 152 с.

2. Азаренков А.А. Дальневосточная республика как периферийная модель преодоления системного кризиса традиционной империи // Гражданская война на востоке России (ноябрь 1917 - декабрь 1922 г.): сборник материалов Всероссийской научной конференции с международным участием (18-20 ноября 2019 г.). Новосибирск: СО PAH, 2019. C. $178-186$.

3. Беляева Н.А., Лаврик Л.А., Ляпустин С.Н. Таможенное дело в Дальневосточной республике. Владивосток: Владивостокский филиал Таможенной академии, 2018. 113 c.

4. Беспалько Д.Н. Особенности развития пушно-сырьевого сектора экономики на территории Забайкалья в период существования Дальневосточной республики (1920-1922 гг.) // Историко-экономические исследования. 2019. № 4. С. 640-664.

5. Большакова О.В. Имперский поворот в изучении истории России: Современная историография. М.: ИНИОН РАН, 2019. 180 с.

6. Великая российская революция и Дальний Восток: международная научная конференция. Сб. материалов. Владивосток: Изд-во ДВФУ, 2018. 308 с.

7. Гражданская война и интервенция на российском Дальнем Востоке: к 100-летию начала Гражданской войны в России (международная научная конференция, г. Владивосток, 23-24 октября 2018 г.) // Россия и АТР: научный журнал: гуманитарные проблемы стран Азиатско-Тихоокеанского региона (АTP) N. 1 (103) / Март 2019.

8. Дальневосточная республика: становление, борьба с интервенцией (февр. 1920-нояб. 1922 г.): В 2 ч. Владивосток: Дальнаука, 1993.

9. Девятые Гродековские чтения: материалы Межрегиональной научно-практической конференции, посвященной 100-летию начала Гражданской войны в России 
"Дальний Восток России на переломе эпох", 17-22 апреля, 2018 г., Хабаровск. В 3 тт. Хабаровск: ХКМ им. Н.И. Гродекова, 2018.

10. Орнацкая Т.А., Цуканов С.С. Судебные учреждения Дальневосточной республики: организационное строительство и подбор кадров // Клио. 2019. № 1. С. 60-64.

11. Позняк Т.З. Повседневная жизнь Владивостока от Первой мировой до Гражданской войны (1914-1922): очерки истории. Владивосток: Дальнаука, 2018. $711 \mathrm{c.}$

12. Покацкий В. А. Денежное обращение Дальневосточной республики 19201922 гг. // Вестник Восточно-Сибирского государственного института культуры. 2018. № 1. C. 5-12.

13. Сердюк М.Б., Чепик М. В. Органы безопасности Дальневосточной республики (1920-1922 гг.): исторический опыт становления кадрового состава // История: факты и символы. 2017. № 4. С. 158-164;

14. Ципкин Ю.Н. Внешняя политика Дальневосточной Республики (1920-1922 гг.). Хабаровск: Изд-во Хабаровского краевого музея, 2019. 173 с.

15. Ципкин Ю.Н. Дальневосточная республика: опыт демократической альтернативы // Из истории Гражданской войны на Дальнем Востоке: Сб. науч. ст. Хабаровск: РИО ДВ ГНБ, 1999. С. 119-146.

16. Чепик М.В. Деятельность государственной политической охраны по обеспечению безопасности Дальневосточной республики (1920-1922 гг.). М.: Эдитус, 2017. 159 c.

17. Sablin I. The Rise and Fall of Russia's Far Eastern Republic, 1905-1922. Nationalisms, Imperialisms, and Regionalisms in and after the Russian Empire. London, New York: Routledge, 2019. 312 p.

18. Smele J. The "Russian" Civil Wars, 1916-1926: Ten Years That Shook the World. Oxford: Oxford University Press, 2016. 423 p.

19. Smith S. A. Russia in Revolution: An Empire in Crisis, 1890 to 1928. Oxford: Oxford University Press, 2018. 480 p.

20. Steinberg M. The Russian Revolution, 1905-1921. Oxford: Oxford University Press, 2017. $400 \mathrm{p}$

\section{Транслитерация по ГОСТ 7.79-2000 система Б}

1. Azarenkov A.A. "Demokraticheskij kompromiss": ideya "bufera" na Dal'nem Vostoke v planakh i taktike politicheskikh sil - uchastnikov grazhdanskoj vojny v Rossii (yanvar' 1920-yanvar' 1921 gg.). Komsomol'sk-na-Amure: Izd-vo Komsom.-na-Amure gos. ped. un-ta, 2001. 152 s.

2. Azarenkov A.A. Dal'nevostochnaya respublika kak periferijnaya model' preodoleniya sistemnogo krizisa traditsionnoj imperii // Grazhdanskaya vojna na vostoke Rossii (noyabr' 1917 - dekabr' 1922 g.): sbornik materialov Vserossijskoj nauchnoj konferentsii s mezhdunarodnym uchastiem (18-20 noyabrya 2019 g.). Novosibirsk: SO RAN, 2019. S. $178-186$

3. Belyaeva N.A., Lavrik L.A., Lyapustin S.N. Tamozhennoe delo v Dal'nevostochnoj respublike. Vladivostok: Vladivostokskij filial Tamozhennoj akademii, 2018. 113 s.

4. Bespal'ko D.N. Osobennosti razvitiya pushno-syr'evogo sektora ehkonomiki na territorii Zabajkal'ya v period sushhestvovaniya Dal'nevostochnoj respubliki (1920-1922 gg.) // Istoriko-ehkonomicheskie issledovaniya. 2019. № 4. S. 640-664.

5. Bol'shakova O.V. Imperskij povorot v izuchenii istorii Rossii: Sovremennaya istoriografiya. M.: INION RAN, 2019. 180 s.

6. Velikaya rossijskaya revolyutsiya i Dal'nij Vostok: mezhdunarodnaya nauchnaya konferentsiya. Sb. materialov. Vladivostok: Izd-vo DVFU, 2018. 308 s.

7. Grazhdanskaya vojna i interventsiya na rossijskom Dal'nem Vostoke: k 100-letiyu nachala Grazhdanskoj vojny v Rossii (mezhdunarodnaya nauchnaya konferentsiya, g. Vladivostok, 23-24 oktyabrya 2018 g.) // Rossiya i ATR: nauchnyj zhurnal: gumanitarnye problemy stran Aziatsko-Tikhookeanskogo regiona (ATR) N. 1 (103) / Mart 2019.

8. Dal'nevostochnaya respublika: stanovlenie, bor'ba s interventsiej (fevr. 1920-noyab. 1922 g.): V 2 ch. Vladivostok: Dal'nauka, 1993.

9. Devyatye Grodekovskie chteniya: materialy Mezhregional'noj nauchno-prakticheskoj konferentsii, posvyashhennoj 100-letiyu nachala Grazhdanskoj vojny v Rossii "Dal'nij Vostok Rossii na perelome ehpokh", 17-22 aprelya, 2018 g., KHabarovsk. V 3 tt. KHabarovsk: KHKM im. N.I. Grodekova, 2018.

10. Ornatskaya T.A., TSukanov S.S. Sudebnye uchrezhdeniya Dal'nevostochnoj respubliki: organizatsionnoe stroitel'stvo i podbor kadrov // Klio. 2019. № 1. S. 60-64.

11. Poznyak T.Z. Povsednevnaya zhizn' Vladivostoka ot Pervoj mirovoj do Grazhdanskoj vojny (1914-1922): ocherki istorii. Vladivostok: Dal'nauka, 2018. 711 s.

12. Pokatskij V. A. Denezhnoe obrashhenie Dal'nevostochnoj respubliki 1920 1922 gg. // Vestnik Vostochno-Sibirskogo gosudarstvennogo instituta kul'tury. 2018. № 1. S. $5-12$. 
13. Serdyuk M.B., CHepik M. V. Organy bezopasnosti Dal'nevostochnoj respubliki (1920-1922 gg.): istoricheskij opyt stanovleniya kadrovogo sostava // Istoriya: fakty i simvoly. 2017. № 4. S. 158-164;

14. TSipkin YU.N. Vneshnyaya politika Dal'nevostochnoj Respubliki (1920-1922 gg.). KHabarovsk: Izd-vo KHabarovskogo kraevogo muzeya, 2019. 173 s.

15. TSipkin YU.N. Dal'nevostochnaya respublika: opyt demokraticheskoj al'ternativy // Iz istorii Grazhdanskoj vojny na Dal'nem Vostoke: Sb. nauch. st. KHabarovsk: RIO DV GNB, 1999. S. 119-146.

16. CHepik M.V. Deyatel'nost' gosudarstvennoj politicheskoj okhrany po obespecheniyu bezopasnosti Dal'nevostochnoj respubliki (1920-1922 gg.). M.: EHditus, 2017. 159 s.

17. Sablin I. The Rise and Fall of Russia's Far Eastern Republic, 1905-1922. Nationalisms, Imperialisms, and Regionalisms in and after the Russian Empire. London, New York: Routledge, 2019. 312 p.

18. Smele J. The "Russian" Civil Wars, 1916-1926: Ten Years That Shook the World. Oxford: Oxford University Press, 2016. 423 p.

19. Smith S. A. Russia in Revolution: An Empire in Crisis, 1890 to 1928. Oxford: Oxford University Press, 2018. 480 p.

20. Steinberg M. The Russian Revolution, 1905-1921. Oxford: Oxford University Press, 2017. 400 p.

Богомолов И. К. Рецензия на книгу Sablin I. The Rise and Fall of Russia's Far Eastern Republic, 1905-1922. Nationalisms, Imperialisms, and Regionalisms in and after.

В рецензии рассматривается монография И. Саблина о возникновении и падении Дальневосточной республики (ДВР). Автор отмечает, что сама идея создания "буферного государства" была уникальной для революционной России, уникальной для большевиков, уникальной для региона. На основании широкого круга источников И. Саблин показывает, как идеологии, с которыми большевики изначально боролись "левый либерализм", национализм и империализм - позволили им в итоге одержать верх на Дальнем Востоке и окончательно победить в Гражданской войне.

Ключевые слова: Дальневосточная республика, Первая мировая война, революиия 1917 г., Гражданская война в России, интервениия, Приамурский зелский край, А.М. Краснощеков, атаман Селенов, каппелевцы

Bogomolov I. K. Review on Sablin I. The Rise and Fall of Russia's Far Eastern Republic, 1905-1922. Nationalisms, Imperialisms, and Regionalisms in and after the Russian Empire.

The review considers the monograph by Ivan Sablin on the emergence and fall of the Far Eastern Republic (FER). The author notes that the very idea of creating a "buffer state" was unique for revolutionary Russia, unique for the Bolsheviks, unique for the region. Based on a wide range of sources Ivan Sablin shows how the ideologies with which the Bolsheviks initially fought - "left liberalism", nationalism and imperialism - allowed them to ultimately gain the upper hand in the Far East and finally win the Civil War.

Key words: Far Eastern Republic, World War I, Russian revolution, Russian Civil War, intervention, Provisional Priamurye Government, A.M. Krasnoshchekov, Ataman Semyonov, kappelevtsy

Для цитирования: Богомолов И. К. Рецензия на книгу Sablin I. The Rise and Fall of Russia's Far Eastern Republic, 1905-1922. Nationalisms, Imperialisms, and Regionalisms in and after // Ойкумена. Регионоведческие исследования. 2020. № 4. C. 158-162. DOI: 10.24866/19986785/2020-4/158-162

For citation: Bogomolov I. K. Review on Sablin I. The Rise and Fall of Russia's Far Eastern Republic, 1905-1922. Nationalisms, Imperialisms, and Regionalisms in and after the Russian Empire // Ojkumena. Regional researches. 2020. № 1. P. 158-162. DOI: 10.24866/1998-6785/2020-4/158162 